\title{
Turist Rehberlerinin Liderlik Tarzlarının Belirlenmesine Yönelik Bir Araştırma: Çanakkale Rehberler Odası Örneği
}

DOI: 10.26466/opus.690593

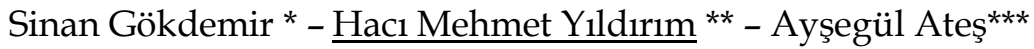 \\ * Dr. Öğr. Üyesi, Çanakkale Onsekiz Mart Üniversitesi, Turizm Fakültesi, Çanakkale/Türkiye \\ E-Posta: sinan.gokdemir@yahoo.com \\ ORCID: 0000-0002-9360-086X \\ ** Doç. Dr., Çanakkale Onsekiz Mart Üniversitesi, Turizm Fakültesi, Çanakkale/Türkiye \\ E-Posta: h.mehmet@comu.edu.tr \\ ORCID: 0000-0003-0718-7296 \\ ***Y.L, Çanakkale Onsekiz Mart Üniversitesi, Sosyal Bilimler Enstitüsü, Çanakkale/Türkiye \\ E-Posta: okyanusa@hotmail.com \\ ORCID: 0000-0001-5160-1226
}

Öz

Turlarn organize edilmesi faaliyetinde etkin bir role sahip turist rehberleri, turizm sektörünün önemli paydaşlarmdandır. Turist rehberleri, gelen ziyaretçilere bir destinasyonun tanttılmasında ve tecrübe ettirilmesinde en etkin turizm paydaşıdır. En temel tanımıyla turist rehberi, bir ülke/bölgenin soyut ve somut kültürel mirası hakkında ziyaretçileri bilgilendiren ve onlara tecrübeleri sırasında rehberlik eden kişidir. Turist rehberlerinin liderlik özellikleri, sahip oldukları bilgi, yetenekler ile belirli bir grubu harekete geçirmek ve belirlenen amaçlarn gerçekleştirmek amactyla hizmet vermeleri, onlarm lider olarak kabul edilmelerini sağlayabilmektedir. Çalışmanın temel amacı, turist rehberlerinin liderlik tarzlarının belirlenmesidir. Araştırma evrenini Turist Rehberleri Birliği (TUREB)'den ruhsatname almıs ve Çanakkale Rehberler Odası (ÇARO)'ya kayıtlı 159 turist rehberi oluştururken, araştırma örneklemini ise ÇARO'dan çalışma kartı almış (eylemli) 121 turist rehberi oluşturmaktadır. Elde edilen sonuçlardan turist rehberlerinin benimsedikleri liderlik tarzının, daha çok otokratik liderlik özelliği taşıdığı ve tur yönetimlerini bu eğilimde gerçekleştirdikleri anlaşılmaktadır.

Anahtar Kelimeler: Turist Rehbeliği, Liderlik Türleri, Çanakkale Rehberler Odası 


\title{
A Research on Determining the Leadership Type of Tourist Guides: The Sample of Canakkale Tourist Guides Chamber
}

\begin{abstract}
Tourist guides, who play an active role in organizing the tours, are important stakeholders in the tourism sector. Tourist guides are the most effective tourism stakeholders in introducing and experiencing a destination to tourists. The leadership skills of tourist guides can provide them to be accepted as a leader by group, if they use their knowledge and skills to activate the group and pointed goals. The main purpose of the study is to determine the leadership types of the tour guides in Canakkale Chamber of Guides (ÇARO). The research population is 159 tourist guide who has a license from the Turkey Tourist Guides Association (TUREB) and registered to Canakkale Chamber of Tourist Guides (CARO). The sample of the research is 121 tourist guides who have working cards from ÇARO. From the obtained results, it is understood that the leadership style of the tour guides is more autocratic leadership and they make tour management in this tendency.
\end{abstract}

Keywords: Tourist Guidance, Leadership Styles, Çanakkale Chamber of Guides. 


\section{Giriş}

Dünyada her yıl milyonlarca insan dinlenmek, yeni yerler görmek gibi çeşitli sebeplerle turizm faaliyetine katılmaktadır. Bu faaliyetin bütünü olan paket turların yürütülmesinde ise turist rehberleri etkin rol almaktadırlar. Kişilerin satın aldıkları paket tur kapsamında veya bireysel olarak katıldıkları gezilerde, ziyaret edilen çekim merkezleri ile ilgili ihtiyaç duydukları bilgilerin turist rehberlerince karşılanması, turist rehberlerinin turizm hareketindeki yerinin ne derece önemli ve vazgeçilmez olduğunun bir göstergesidir. Ziyaret edilen bölge ve ülkenin tanıtımında, ziyaretçilerde olumlu deneyimlerin yaşatılmasında etkili rol oynayan turist rehberleri, rehberlik yaptıkları kültürün birer temsilcisi olarak, o kültürü merak eden ve öğrenmek isteyenlere istedikleri dillerde bilgi aktarımında bulunurlar. Ayrıca turist rehberleri, kişisel özellikleri ve sosyal iletişim becerileriyle, turistlerin ziyaret ettikleri ülke/bölgeden beklentilerinin karşılamasına ve ziyaretçi kültürü ile ziyaret edilenler kültürü arasında bağ kurulmasına katkı sağlayan yegâne kişilerdir (Kozak, 2017).

Seyahat acentaları ya da tur operatörleri tarafindan oluşturulan turların uygulanması ve yürütülmesinde aktif rol alan turist rehberleri, ziyaretçilere verdikleri hizmet sebebiyle turizm ürünün bir unsuru olarak kabul edilmektedirler. Turist rehberlerinin benimsedikleri liderlik tarzları, tur süresince veya sonrasında turistlerin memnuniyetlerine etki ederek, onların sadakatini kazanma gibi olumlu sonuçlar yaratabilmesinin dışında, turdan memnun kalmama gibi anlaşmazlıklara yol açan olumsuz sonuçların doğmasına da neden olabilmektedir (Wong ve Lee, 2011). Turizm de dahil olmak üzere birçok farklı alandaki tüketiciler satın aldıkları ürün ve hizmetlerle ilgili memnuniyetlerini ya da memnun kalmama gibi olumsuz düşüncelerini aileleri, arkadaşları veya diğer insanlarla ağızdan ağıza iletişim yoluyla paylaşmaktadırlar (Çaylak ve Tolon, 2013). Bu durumdan hareketle, katıldığ1 turdan memnun olan ya da memnun olmayan bir turist, çevresinde bulunan potansiyel turistleri de olumlu ya da olumsuz anlamda etkileyebilmektedir. Turist rehberliği hizmetini satın alan misafirlerin, satın aldıkları rehberlik hizmetine ilişkin memnuniyet değerlendirmelerini, negatif ya da pozitif etki bırakacak yönde ağızdan ağıza iletişim yoluyla diğer insanlarla paylaşmaları kaçınılmazdır. Turist rehberlerinin liderlik tarzlarının belirlenmesi ve elde edilen so- 
nuçlara göre ortaya çıkan liderlik türleri çerçevesinde tur yönetim önerilerinin belirlenmesi, olası olumsuzlukların önüne geçilmesini ve bunun da rehberlik mesleğinin öneminin anlaşılmasına olumlu katkı sağlayabileceği düşünülmektedir. Turist rehberlerinin liderlik tarazlarının belirlenmesine mesleki açıdan bakıldığında ülkemizde 6326 sayılı Turist Rehberliği Meslek Kanunu ve Turist Rehberliği Meslek Yönetmeliği hükümlerine göre faaliyet gösteren turist rehberlerine, eğitim aldıkları kurumlarca liderlik tarzları ile ilgili eğitim verilmediği anlaşılmakta olup, uygulamada turist rehberlerinin kendi liderlik tarzlarını kendilerinin belirlediği gözlemlenmiştir. Bu gözlem 1ş1ğında, turist rehberlerinin liderlik tarzlarının belirlenmesinin, onların mesleki gelişimlerine pozitif yönde etki edebileceği ve uygulamada turist rehberlerinin belirlenen liderlik tarzları doğrultusunda faaliyette bulunabilecekleri söylenebilir.

\section{Kavramsal Çerçeve}

\section{Turist Rehberliği ve Türleri}

Antik çağlardan günümüze, zaman içinde yolculukların yapılma sebepleri değişse de gerek bilgileri gerekse tecrübeleriyle rehberlerin gidilecek yolun belirlenmesi ile ilgili üstlendikleri temel görev bugün halen aynıdır. Türk Dil Kurumu rehberi "yol gösterici, kılavuz" olarak tanımlamakta olup, turist rehberliğine ilişkin alan yazında farklı tanımlamaların olduğu görülmektedir (TDK, 2020) . Ahipaşaoğlu (2001) turist rehberini, önceden belirlenmiş bir program çerçevesinde, ziyaret edilen yerlerle ilgili doğru bilgiyi, ziyaretçilere uygun bir dille aktaran, ziyaret edilen ülke veya bölgenin tanıtımını gerçekleştiren, seyyahlara ekonomik, sosyal ve kültürel edinimler sağlayan bir kişi olarak ifade etmiştir. Cohen (2002), rehberler ve danışmanlar olmak üzere ikili bir ayrımla turist rehberliğini açıklamıştır. Bu ikili ayrıma göre, rehberlerden beklenenin yolları ve ilgi odağı olan yerleri ziyaretçilere göstermeleri iken, danışmanlardan beklenenin ise gidilen yerlerde ziyaretçilerin nasıl davranmaları gerektiğini onlara öğretmeleridir. Yarcan (2007) ise turist rehberini "yerli ve yabanc ziyaretçilerin seçtiği dilde müze ve ören yerlerini gezdiren, gezi yerlerini ve anıtları yorumlayan, doğal ve kültürel çevreyi ve kalıtları zevkli bir biçimde tanıtan ve gezilerinde ziyaretçilere eşlik eden profesyonel turizm çalışanı" olarak tanımlamıştır. 
Türkiye'de turist rehberliği 07.06.2012 tarih ve 6326 sayılı Turist Rehberliği Meslek Kanunu'nda düzenlenmiş olup, bu kanun kapsamında mesleğe kabul ile "turist rehberliği hizmeti sunma hak ve yetkisine sahip olan gerçek kişiler" turist rehberi olarak kabul edilmektedir (TRMK, 2012). Dünya Turist Rehberleri Federasyonları Birliği (World Federation of Tourist Guide Associations-WFTGA) ise turist rehberini "ziyaretçilere seçtikleri dilde kılavuzluk yapan ve ilgili bölgenin otoritesi tarafından belirlenen özelliklere sahip, bir bölgenin doğal ve kültürel mirası hakkında bilgi veren kişi" olarak tanımlamaktadır (World Federation of Tourist Guide Associations, Erişim Tarihi: 07 Mayıs 2020). Dünyada ve Türkiye'de turizm faaliyetine katılan turist sayısı her geçen gün arttıkça, turist rehberlerine duyulan ihtiyacın da artacağı düşünülebilir. Bu kapsamda, Türkiye' de faaliyette bulunan turist rehberlerinin önceleri Turizm Bakanlığına ve daha sonraki yıllarda Kültür ve Turizm Bakanlığına bağlı olarak faaliyet gösterdikleri anlaşılmakta olup, günümüzde turist rehberleri bu faaliyetlerini Turist Rehberleri Birliğine bağlı olarak yürütmektedirler. Tablo1'de Türkiye'deki turist rehberi sayıları yıllara göre verilmiştir.

Tablo1. Türkiye'deki Yıllara Göre Turist Rehberi Sayıları

\begin{tabular}{lll}
\hline Y1l & Turist Rehberi Sayısı & Bağlı Bulunan Kurum \\
\hline 1980 & 211 & Turizm Bakanlığ1 \\
\hline 1985 & 1150 & Turizm Bakanlığ1 \\
\hline 1990 & 4703 & Turizm Bakanlığ1 \\
\hline 1997 & 6163 & Turizm Bakanlığ1 \\
\hline 2000 & 7684 & Turizm Bakanlığ1 \\
\hline 2012 & 13241 & Kültür ve Turizm Bakanlı̆̆1 \\
\hline 2015 & 9800 & TUREB \\
\hline 2016 & 9746 & TUREB \\
\hline 2017 & 10308 & TUREB \\
\hline 2018 & 10408 & TUREB \\
\hline 2019 & 11060 & TUREB \\
\hline
\end{tabular}

Kaynak: Arslantürk vd. (2016); TUREB, 2018.

Turist Rehberleri Birliği'nin (TUREB) 2018 yılı verilerine göre Çanakkale Rehberler Odası (ÇARO)'ya toplamda 159 turist rehberi kayitlı olup, odaya kayıtlı rehberlerin 121 tanesi çalışma kartına sahiptir (TUREB, 2018). 
Turist rehberi tanımlarından yola çlkarak, turist rehberinin görevinin yalnızca ziyaretçileri bilgilendirmek ve yol göstermek olmadığını, bilgi aktarımında bulunurken ziyaretçilerde uyandıracağı olumlu izlenimlerle, ziyaret edilen bölgenin, ülkenin tanıtımına ve kültürlerarası etkileşime katkı sağlayabilecek önemde bir göreve sahip olduklarını da söyleyebiliriz. Turist rehberleri 6326 sayılı Turist Rehberliği Meslek Kanunu'nda tanımlanan rehberlik hizmeti "seyahat acentalı̆̆ faaliyeti niteliğinde olmamak kaydryla kişi veya grup halindeki yerli ve yabancı turistlerin gezi öncesinde seçmiş oldukları dil kullanılarak ülkenin kültür, turizm, tarih, çevre, doğa, sosyal ve benzeri değerleri ile varlıklarmın kültür ve turizm politikaları doğrultusunda tanttlarak gezdirilmesini veya seyahat acentalar tarafindan düzenlenen turlarm gezi programmin seyahat acentasinin yazılı belgelerinde tanımladığı ve tüketiciye satıldığı şekilde yürütülüp acenta adına yönetilmesi" şeklinde tanımlanmıştır. (TRMK, 2012).

Rehberlik hizmetinden doğan görevlerini yerine getirirken kanuna ve etik kurallara uyma yükümlülüğü altında bulunan turist rehberlerinin, kanunla belirlenen görevleri dışında beşerî ilişkileri, kişisel çabaları, sahip oldukları liderlik özellikleri ile turun en iyi şekilde yönetilmesine, tura katılanların grup bilinciyle hareket etmelerine ve problemlere çözüm bulmaya yönelik görevleri de vardır (Kozak, 2017). Turist rehberlerinin farklı alanlarda ve farklı hedef kitlelerine hizmet vermeleri, onların mesleki anlamda bir siniflandırma içinde yer almaları gereğini ortaya çıkarmaktadır.

Her turistin ilgi duyduğu destinasyon birbirinden farklı olabileceği gibi her rehberin de ziyaretçilerine tecrübe ettirdiği deneyimler birbirinden farklı olabilmektedir. Turist rehberlerinin, ziyaretçi profillerine göre kendilerine uzmanlık alanları belirleyerek rehberlik hizmeti vermelerinin, turist rehberlerinin sınıflandırılmasına olumlu katkı sağlayacağı ileri sürülebilir. Literatür incelemesinde turist rehberlerinin sinıflandırılmasının farklı başlıklar altında yapılmış olduğu görülmekle birlikte, açılamalarda daha çok kanuni sınıflandırmanın temel alındığı belirlenmiştir. Buna göre turist rehberlerinin sınıflandırılması dört ana başlık altında açıklanabilir (Gökdemir, 2017);

- Kanuni düzenlemeye göre rehberler

- Uzmanlık alan bilgisine göre rehberler

- Çalışma bölgesine göre rehberler

- Çalışma süresine göre rehberler 
Kanuni düzenlemeye göre rehberler, 22 Haziran 2012 tarihli Resmî Gazete'de yayımlanarak yürürlüğe giren 6326 sayılı Turist Rehberliği Meslek Kanunu'nda bir meslek olarak düzenlemesi yapılan turist rehberliği, kanunda eylemli ve eylemsiz turist rehberi olarak düzenlenmiş olup, eylemli ve eylemsiz turist rehberi de ülkesel ve bölgesel olmak üzere ikili bir ayrım yapılarak tanımlanmıştır. Bu yasal ayrımlara göre, çalışma kartına sahip turist rehberleri eylemli turist rehberi olarak kabul edilirken, turist rehberi ruhsatnamesine sahip olup ancak çalışma kartı olmayan turist rehberleri de eylemsiz turist rehberi olarak kabul edilmektedir (TRMK,2012).

Uzmanlık alan bilgisine göre rehberler ise turist rehberlerinin, ilgilerini çeken konular hakkında aldıkları eğitimler çerçevesinde rehberlik faaliyetinde bulunmaları ve bu alanlarda uzmanlaşmalarına yönelik bir sınıflandırmadır. Örnek olarak Selçuklu eserleri, su kemerleri, antik çăg, müzeler, ören yerleri gibi konular bir uzmanlık konusu olarak seçilebileceği gibi avcllık, doğa yürüyüşü gibi etkinlikler de bir uzmanlığa konu olabilmektedir (Gökdemir, 2018).

Çalışma bölgesine göre rehberler, 6326 sayılı Turist Rehberliği Meslek Kanununda, rehber adaylarının tüm Türkiye'yi kapsayan veya bir ya da birden fazla bölgeye ilişkin tamamladıkları eğitim gezileri doğrultusunda ülkesel veya bölgesel olarak rehberlik hizmeti faaliyetinde bulunabilmeleri bu siniflandırmanın temel dayanağıdır (TRMK, 2012).

Çalışma süresine göre rehberler, turist rehberlerinin, rehberlik sözleşmesi ile konaklama olmayan günübirlik geziler veya paket tur kapsamında en az bir gece konaklamayı içeren rehberlik hizmetini ziyaretçilere sunmalarına yönelik bir ayrımla ilgilidir (Çolakoğlu vd., 2017). Belirtilen sınıflandırmaların haricinde, turist rehberlerinin sahip oldukları liderlik özellikleri ile uygulamada rehberlik hizmeti sunarken benimsedikleri liderlik tarzlarının belirlenmesinin de ayrı bir sınıflandırmaya konu olabileceği öne sürülebilir.

\section{Liderlik ve Liderlik Teorileri}

Liderlik, belirlenen hedeflerin gerçekleştirilmesi gayesiyle kişisel özellikleri, davranışları ile bir grubun kendi arkasından gelmesini sağlayabilen, her kademedeki insanın yerine getirebileceği bir görev, kişilerarası bir etkileşim süreci olarak tanımlanmıştır (Ulukan, 2006). Keçecioğlu'na (1998) göre sosyal 
bir etkileme sürecinden kaynaklanan liderlik, belirli bir amacın gerçekleştirilmesi için kişilerin sahip olduğu özellikler ile diğer insanları etkileyebilme gücü olarak ifade edilmiştir (Ülgen ve Mirze, 2010). Literatür incelendiğinde liderlik ile ilgili ortaya konulan teorilerin farklı isimler ve başlıklar ile açıklandığ1 görülmüsştür. Sabuncuoğlu ve Tüz (2016) liderlik teorilerini özellikler, davranış ve durumsallık olmak üzere üç başlıkta incelemişlerdir.

Özellikler teorisi, liderin kişisel özelliklerini temel alan bir teoridir (Sabuncuoğlu ve Tüz, 2016). Diğer yandan Kozak (2017) özellikler teorisini, sonradan öğrenilmesinin mümkün olmayacağı düşünülen ve lideri diğer insanlardan ayıran özelliklerinin, onun başkaları tarafından lider olarak benimsenmesini sağlayan, kişiye özgü bir yetenek olduğu görüşüyle açıklamaktadır. Liderliği özellikler teorisi ile açıklanmaya çalışan araştırmacılar zamanla bu teorinin yetersiz kalması ile liderlerin davranışlarını araştırmalarına konu edinmişlerdir (Sabuncuoğlu, 2016).

Davranış teorisi, liderliği açıklamaya çalışan özellikler teorisinin tüm sorulara yanıt veremediğinin düşünülmesiyle ortaya çıkmıştır. (Ardahan vd., 2016). Liderin davranışlarının ön plana çıktığı bu teoride, liderin önderlik ettiği grup ile olan iletişimine, planlamaya, kontrole, yetki devrine ve benzeri faaliyetlerine yönelik davranışları, etkin bir liderliğin belirlenmesini sağlayan unsurlardan bazıları olduğu literatürde kabul edilmektedir (Sabuncuoğlu, 2016). Davranış teorisinde lider davranışlarının otokratik veya demokratik özellikler gösterebileceği, bunun belirleyicisinin ise liderin birlikte çalıştığ grup üyelerinin lidere ve liderin de grup üyelerine olan bakış açısının olduğunu söylemek mümkündür (Kozak, 2017). Davranış teorisi yalnızca otoktarik ve demokratik liderlik davranışlarını içermeyip, serbest bırakıcı liderlik davranışlarını da inceleme konusu yapmaktadır (Russell, 2001).

Durumsallık teorisi, liderin bulunduğu ortamın özelliklerinin ve farklı koşulların ortaya çıkardığı ihtiyaçların liderin davranışlarını ve dolayısıyla çalışanları etkileyen liderlik tarzlarının temel alındığı bir yaklaşımdır (Sabuncuoğlu, 2016). Liderin davranışlarını değişen koşullara göre belirlemesi, durumsallık teorisi başlığı altında yer alan çalışmalardan Fidler ve arkadaşlarının benimsediği "işe yönelik" ve "ilişkiye yönelik" liderlik tarzlarından herhangi birinin mutlaka uygulanması gereğini ortadan kaldırarak, lidere, değişen şartlara uygun, farklı davranışlar sergileme imkanı verdiği literatürde kabul görmektedir (Kozak, 2017). 
Liderlik teorileri üzerine yapılan çalışmaların liderlerin, liderlik tarzlarının belirlenmesine öncülük ettiği düşünüldüğünde bu çalışma açısından, turist rehberlerinin liderlik tarzlarının belirlenmesine, otokratik, demokratik, serbest bırakıcı, dönüşümcü ve etkileşimci liderlik tarzları esas teşkil etmektedir (Taş vd. 2007).

Otokratik liderlik tarzında, turist rehberi turun yönetim yetkisini yalnızca kendisinde toplamakla birlikte, grup üyelerini etkilemek gayesiyle onlara emirler vererek ve onların hatalarını eleştirerek bir cezalandırma taktiği uygulayabilmektedir. Otokratik turist rehberinin verdiği talimatlarl, turda yer alan ziyaretçiler koşulsuz yerine getirme yükümlülüğü altındadır (Sabuncuoğu, 2016). Otokratik turist rehberi kararları kendisi alırken, turist grubunun bu karar verme sürecine dahil edilmeyişi otokratik liderlik tarzının en belirgin özelliğidir (Keçecioğlu, 1998).

Demokratik liderlik tarzında, yönetime ilişkin yetkilerini turist grubu ile paylaşmaya eğilimli olan ve onların tura uyumların etkileyen durumların belirlenmesi için onların düşüncelerine, önerilerine önem verdiğini gösteren turist rehberi, aynı zamanda, uzmanlığı ve çekim gücüyle grubu etkileyerek, turun karar alma dışındaki faaliyetlerinin, kendisi olmaksızın, kendiliğinden gerçekleştirilmesini sağlayan kişidir (Sabuncuoğlu 2016).

Dönüşümcü liderlik tarzında turist rehberi, ziyaretçileri sahip olduğu karizması, entelektüel bakış açısı, kendine olan güveni, vizyon yaratıcı, ilham verici özellikleri ve içten davranışlarıyla etkileyebilmektedir. Turu satın alan kişilerin, içinde oldukları tur grubunun beklentilerini, kendi kişisel beklentilerinin üzerinde görmelerini sağlayan dönüşümcü rehber, tura katılanların tatil sırasında uymaları gereken kuralları istekle yerine getirmelerine ışık tutmaktadır (Ülgen, 2010). Tur gruplarının mevcut olması, turist rehberlerinin de var olacağı gerçeğini ortaya koymakta olup (Yayla vd. 2014), günümüzün hızla değişen koşullarında, seyahat acentaları ve turist grupları açısından dönüşümcü turist rehberlerine duyulan ihtiyacın onları, zorunlu bir öğe haline getirdiği düşünülmektedir (Kozak, 2017).

Serbest bırakıc liderlik tarzında, turun yönetimine ilişkin yetkilerini nadiren kullanarak sorumluluk almaktan kaçınan, düşüncelerini açıç̧a belli etmeyip, kendisine danışıldığında görüşlerini beyan eden, grubu serbest bırakarak onların turdan nasıl tatmin sağlayacaklarını kendilerine bırakan serbest bırakıcı rehber, yönettiği gruba sağladığı kaynaklar ve bu kaynaklarla 
ilgili ortaya çıabilecek sorunlara çözüm getirme gayesi ile hareket etmektedir (Sabuncuoğlu, 2016). Serbest bırakıc liderlik tarzına sahip bir turist rehberi yönetimindeki grup üyelerinin performans ve doyumunun, otokratik liderlik tarzına sahip bir turist rehberi yönetimindeki grup üyelerinden daha yüksek olduğu ifade edilmektedir (Keçecioğlu, 1998).

Etkileşimci liderlik ise Burns (1978) tarafından geliştirilmiş ve kendini takip edenlerin liderlerin gelişimlerine katkı sağlayan beklentilerini karşılaması sonucunda prestij ve katkı sağlamakta, lider ve takip eden arasında karşlıklı çıkarlara dayanan bir süreç olarak tanımlanmıştır (Arzi ve Farahbod,2014). Etkileşimci liderlik tarzında turist rehberi, karşılıklı bir etkileşim yaratarak, aynı zamanda tur hedeflerinin gerçekleştirilmesi açısından onlara sorumluluklar da yüklemektedir.

Turist rehberlerinin sahip oldukları liderlik özellikleri, bakış açıları, turistlere karşı tutum ve davranışları ile farklı liderlik tarzlarının belirlenmesi ihtiyacı karşılanmakla birlikte, gelecekte değişen şartlara ve durumlara uygun yeni liderlik tarzlarının belirlenmesinin mümkün olabileceği ifade edilebilir.

\section{Yöntem}

Çanakkale Rehberler Odasına kayıtlı turist rehberlerinin liderlik tarzlarının ortaya konulmaya çalışıldığı bu araştırmada başta turist rehberliği hizmeti veren rehberler olmak üzere seyahat acentalarıyla diğer turizm paydaşlarını bilgilendirme açısından önemli olduğu düşünülmektedir. Çalışmanın temel amacl; turist rehberlerinin liderlik türleri belirlenmesidir. Araştırmaya katılan turist rehberlerinin liderlik özelliklerinin rehberlerin betimleyici özelliklerine göre farklılık gösterip göstermediğini test etmek için farklılık analizleri yapılmıştır. İlgili alanyazın incelendiğinde, bunun birkaç çalışmada araştırıldığ görülmektedir (Soysal ve diğerleri, 2011; Coşar, 2011; Taşdöven ve diğerleri, 2012; Yücel ve Akgül, 2016; Korkmaz, 2017).

Araştırmanın evrenini, Çanakkale Turist Rehberleri Odasına kayıtlı turist rehberleri oluşturmaktadır. Araştırmanın kapsadığı olgu, olay, obje ve kişilerin tamamına evren denilmektedir (Yazıcıoğlu ve Erdoğan, 2004, s.31). Araştırma örnekleminin hesaplanmasında ise turizm sezonundan kaynaklanan katılımcılara ulaşma konusundaki güçlükler sebebiyle tesadüfî olmayan örnekleme yöntemlerinden bir tanesi olan kolayda örnekleme yöntemi kulla- 
nılmıştır. Bu yöntem, ankete cevap verebilecek her bireyin örneğe dahil edilmesi durumudur ve bu yönteme göre en kolay bulunan katılımcl, en ideal olan katılımcidır (Altunışık ve diğerleri, 2012: 142).

Veri toplama aracı olarak Taş ve diğerleri (2007) tarafından geliştirilen Liderlik Tarzı Davranış Ölçeği kullanılmıştır. Ayrıca katılımcıların demografik verilerini toplamaya yönelik sorulara yer verilmiştir. Liderlik Tarzı Davranış Ölçeği, Taş ve diğerleri (2007) tarafından geliştirilmiştir. Liderlik Tarzı Davranış Ölçeği, beşli likert tipi bir ölçektir. 59 madde içeren ölçek, otokratik liderlik, demokratik liderlik, serbest bırakıc liderlik, dönüşümcü liderlik ve etkileşimci liderlik olmak üzere beş alt boyutu ele almaktadır. Çevirim içi olarak oluşturulan ve katılımcılara sosyal medya üzerinden uygulan anketler; Nisan-Aralık 2018 döneminde toplanmıştır. Toplamda 121 kişiye sosyal medya üzerinden linkler yollanmış, 102 kişiden geri dönüş alınmıştır. Geri dönüş alınan anketlerden elde edilen veriler ile frekans analizi, bağımsız örneklem t-testi ve tek yönlü varyans analizi (ANOVA) yapılmış ve bulgulara ulaşılmıştır. Çalışmaya katılan katılımcıların vermiş oldukları cevaplar doğrultusunda elde edilen veriler analiz edilmiştir. Araştırmaya ilişkin hipotezler aşağıdaki gibi oluşturulmuştur.

- H1: Turist rehberlerinin liderlik tarzları, turist rehberlerinin sosyo-demografik özelliklerine göre farklılık göstermektedir.

- $\mathrm{H}_{2}$ : Turist rehberlerinin liderlik tarzları, turist rehberlerinin mesleki özelliklerine göre farklılık göstermektedir.

- H3: Turist rehberlerinin liderlik tarzları, çıkılan tur grubuna göre farkl1lik göstermektedir.

- $\mathrm{H}_{4}$ : Turist rehberlerinin liderlik tarzları, ziyaretçi uyruğuna göre farkl1lık göstermektedir.

\section{Bulgular}

Turist rehberlerinin liderlik tarzlarının belirlenmesine yönelik çalışmaya katılan rehberlere ait betimleyici bilgiler aşağıda, Tablo 2' de gösterilmiştir. 
Tablo 2.Turist Rehberlerine Ait Betimleyici İstatistikler (N=102)

\begin{tabular}{|c|c|c|c|c|c|}
\hline Cinsiyet & $\mathbf{N}$ & $\%$ & Çalışma Kartı Türü & $\mathbf{N}$ & $\%$ \\
\hline Kadın & 33 & 32,4 & Bölgesel & 10 & 9,8 \\
\hline Erkek & 69 & 67,6 & Ülkesel & 92 & 90,2 \\
\hline Yaş & $\mathbf{N}$ & $\%$ & Meslekte Geçirilen Süre & $\mathbf{N}$ & $\%$ \\
\hline $18-29$ & 12 & 11,8 & 5 yildan az & 28 & 27,5 \\
\hline $30-39$ & 58 & 56,9 & 6-10 yil & 31 & 30,4 \\
\hline $40-49$ & 18 & 17,6 & $11-15$ yil & 20 & 19,6 \\
\hline 50 ve üstü & 14 & 13,7 & 16 yıl ve daha fazla & 23 & 22,5 \\
\hline Aylık Gelir & $\mathbf{N}$ & $\%$ & Çıkılan Grubun Milliyeti & $\mathbf{N}$ & $\%$ \\
\hline 1600 TL'den az & 6 & 5,9 & Yerli & 55 & 53,9 \\
\hline $1601-2500 \mathrm{TL}$ & 19 & 18,6 & Yabanci & 47 & 46,1 \\
\hline $2501-3500 \mathrm{TL}$ & 32 & 31,4 & & & \\
\hline 3501-4500 TL & 25 & 24,5 & Mesleği İcra Etme Şekli & $\mathbf{N}$ & $\%$ \\
\hline \multirow[t]{2}{*}{4500 TL'den çok } & 20 & 19,6 & Asıl İş & 76 & 74,5 \\
\hline & & & Ek İş & 26 & 25,5 \\
\hline Eğitim & $\mathbf{N}$ & $\%$ & & & \\
\hline Önlisans & 22 & 21,6 & Çıkılan Tur Grubu & $\mathbf{N}$ & $\%$ \\
\hline Lisans & 67 & 65,7 & Günübirlik & 72 & 70,6 \\
\hline Lisansüstü & 13 & 12,7 & Anadolu turu & 30 & 29,4 \\
\hline
\end{tabular}

Tablo 2 incelendiğinde turist rehberlerinin 69'unun erkek, 33'ünün ise kadın olduğu görülmekte olup, rehberlerin 58'inin 30 ile 39 yaş aralığında olduğu ve ayrıca 67 'sinin ise lisans mezunu olduğu görülmektedir. Turist rehberlerinin 72 'si çıktı̆ 1 turların günübirlik turlar oluşturduğu ve 31 rehberin meslekte geçirdiği sürenin ise 6 ile 10 yıl arasında olduğu tespit edilmiştir. Çanakkale Rehberler Odasına kayıtlı turist rehberlerinin mevcut durumdaki liderlik tarzlarının değerlendirilmesine ilişkin bulgular Tablo 3'te sunulmuştur.

Tablo 3. Turist Rehberlerin Liderlik Tarzlarna İlişkin Bulgular

\begin{tabular}{lll}
\hline Liderlik Türleri & Ortalama & Görülme Sıklı̆̆ \\
\hline Otokratik Liderlik & 3,05 & Çoğunlukla \\
\hline Serbest Bırakıcı Liderlik & 2,70 & Ara Sıra \\
\hline Etkileşimci Liderlik & 2,33 & Nadiren \\
\hline Demokratik Liderlik & 1,98 & Nadiren \\
\hline Dönüşümcü Liderlik & 1,89 & Nadiren \\
\hline
\end{tabular}

Tablo 3 incelendiğinde, turist rehberlerinin liderlik tarzlarından otokratik liderlik davranışlarını $(3,05)$ "çoğunlukla" gerçekleştirdikleri, serbest bırakıcı lider davranışlarını $(2,70)$ "ara sıra" gösterirmiş oldukları tespit edilmiştir. 
Turist rehberlerinin daha sonra sırasıyla etkileşimci liderlik (2,33), demokratik liderlik $(1,98)$ son olarak da dönüşümcü liderlik özelliklerini $(1,89)$ "nadir" sıklıkta sergiledikleri belirlenmiştir. Turist rehberlerinin mesleki özelliklerine göre bağımsız örneklem t-testine ilişkin bulgular Tablo 4'te sunulmuştur.

Tablo 4. Turist Rehberlerin Mesleki Özelliklerine Göre Bağımsız Örneklem T-Testine İlişkin İstatistikler

\begin{tabular}{|c|c|c|c|c|c|c|c|}
\hline Liderlik Türü & Mesleki Öze & & $\mathbf{N}$ & $\overline{\boldsymbol{X}}$ & $\begin{array}{l}\text { Standart } \\
\text { Sapma }\end{array}$ & $\begin{array}{l}\text { Standart } \\
\text { Hata }\end{array}$ & Sig. \\
\hline \multirow{2}{*}{$\begin{array}{l}\text { Otokratik } \\
\text { Liderlik }\end{array}$} & \multirow{2}{*}{$\begin{array}{l}\text { Çalışma } \\
\text { Şekli }\end{array}$} & $\begin{array}{l}\text { Acentaya } \\
\text { bağll }\end{array}$ & 19 & 3,35 & 60 & ,13 & \multirow{2}{*}{, 006} \\
\hline & & Serbest & 83 & 2,98 &, 50 & ,05 & \\
\hline \multirow{2}{*}{$\begin{array}{l}\text { Etkileşimci } \\
\text { Liderlik }\end{array}$} & \multirow{2}{*}{$\begin{array}{l}\text { Mesleği İcra } \\
\text { Etme Şekli }\end{array}$} & Assl İş & 76 & 2,39 & ,56 & 06 & \multirow{2}{*}{,040 } \\
\hline & & Ek İş & 26 & 2,15 & 49 & ,09 & \\
\hline \multirow{2}{*}{$\begin{array}{l}\text { Serbest Bırakıcı } \\
\text { Liderlik }\end{array}$} & \multirow{2}{*}{$\begin{array}{l}\text { Çalışma } \\
\text { Kartı Türü }\end{array}$} & Bölgesel & 10 & 2,18 & 64 & 20 & \multirow{2}{*}{,004 } \\
\hline & & Ülkesel & 92 & 2,60 & ,39 & ,04 & \\
\hline
\end{tabular}

Tablo 4'e göre turist rehberlerinin mesleki özeliklerine göre yalnızca bazı liderlik türlerinde farklılıklar olması nedeniyle $\mathrm{H}_{2}$ hipotezi kısmen desteklenmiştir. Acentaya bağlı olarak çalışan turist rehberlerinin $(3,35)$ serbest çalışan turist rehberlerine göre daha çok otokratik liderlik özellikleri gösterdikleri tespit edilmiştir. Bu durumun sebepleri arasında rehberlerin acentaların yazdıkları programları zamanında bitirememe kaygısı olduğu söylenebilir.

Turist rehberlerinin mesleği icra etme şekillerine göre ise mesleğini "asıl iş" olarak turist rehberlerinin $(2,39)$ mesleğini "ek iş" olarak yapan turist rehberlerine göre daha fazla etkileşimci liderlik özellikleri gösterdikleri belirlenmiştir. Turist rehberlerinin çalışma kartı türüne göre serbest bırakıcı liderlik boyutunda anlamlı bir fark bulunmuştur. Çalışma kartı türü "ülkesel" nitelikte olan turist rehberlerinin $(2,60)$ çalışma kartı türü "bölgesel" olan turist rehberlerinden daha fazla serbest bırakıcı liderlik özelliklerini benimsedikleri anlaşılmaktadır. Bu durumun sebebi bölgesel rehbrlerin kısa zamanda çok yer tanitma mecburiyetleri gösterilebilir. Turist rehberlerinin gelirlerine ilişkin ANOVA testiyle elde edilen bulgular Tablo 5'te sunulmuştur. 
Tablo 5. Rehberlerin Gelirlerine Göre ANOVA Testi İstatistikleri

\begin{tabular}{|c|c|c|c|c|c|c|c|}
\hline Liderlik Türü & Aylık Gelir & $\mathbf{N}$ & $\bar{X}$ & $\begin{array}{l}\text { Standart } \\
\text { Sapma }\end{array}$ & $\begin{array}{l}\text { Std. } \\
\text { Hata }\end{array}$ & $\mathbf{F}$ & Sig \\
\hline \multirow{5}{*}{$\begin{array}{l}\text { Otokratik } \\
\text { Liderlik }\end{array}$} & 1600 TL'den az & 6 & 3,28 & 0,47 & 0,19 & \multirow{5}{*}{4,79} & \multirow{5}{*}{001} \\
\hline & $1601-2500 \mathrm{TL}$ & 19 & 3,43 & 0,62 & 0,14 & & \\
\hline & $2501-3870 \mathrm{TL}$ & 32 & 2,96 & 0,42 & 0,07 & & \\
\hline & $3871-5000 \mathrm{TL}$ & 25 & 2,80 & 0,58 & 0,12 & & \\
\hline & 5000 TL'den çok & 20 & 3,08 & 0,38 & 0,09 & & \\
\hline
\end{tabular}

Tablo 5'e göre 1601-2500TL gelire sahip olan turist rehberlerinin, diğer gelir aralıklarında yer alan turist rehberlerine göre daha fazla otokratik liderlik özellikleri göstermeleri dolayısıyla turist rehberlerinin liderlik tarzlarının gelirlerine göre farklılık göstermesi bakımından anlamlı bir fark olduğunun tespiti sonucunda $\mathrm{H}_{1}$ hipotezi kısmen desteklenmiştir. Bu durumun sebepleri arasında gelir azlığının tetiklediği mesleki tükenmişlik hissi gösterilebilir.

Yapılan t-testi sonucunda turist rehberlerinin liderlik tarzlarının belirlenmesinde cinsiyete göre anlamlı bir fark olmadığından, $\mathrm{H}_{1}$ kısmen desteklenmiştir. Yapılan analizlerde turist rehberlerinin liderlik tarzları, çıkılan tur grubuna göre ve ziyaretçi uyruğuna göre farklılık göstermediğinden $\mathrm{H}_{3}$ ve $\mathrm{H}_{4}$ hipotezleri desteklenmemiştir.

\section{Tartışma ve Sonuç}

Turist rehberlerinin liderlik tarzlarının belirlenmesine yönelik yapılan bu çalışma ile turist rehberliği mesleğinin gelişimine katkı sağlayacağı düşünülen aşağıdaki sonuçlara ulaşılmıştır. Çanakkale Rehberler Odasına kayıtlı, çalışma kartına sahip ve ankete katılan turist rehberlerinin çoğunluğu orta yaş grubunda ve lisans mezunu erkeklerden oluşmaktadır. Turist rehberinin verdiği hizmet sebebiyle sürekli seyahat halinde olması, çalışma koşullarındaki zorluklar, düzenli bir aile yaşantısının olamayışı gibi çeşitli sebeplerle kadın rehber sayısının, erkek rehber sayısından daha az olduğu düşünülmektedir (Köroğlu, 2011; Çetin, 2012; İrigüler, 2015; Gökdemir, 2017; Gökdemir ve Hacıŏglu, 2018). Çalışma açısından, cinsiyet farklılığının turist rehberlerinin liderlik tarzlarının belirlenmesine bir etkisinin olmadığı sonucunun tespiti, Tosunoğlu (2014) tarafından yapılan “Liderlik tarzı algısının örgütsel bağlılık 
üzerindeki etkisinde örgüte güvenin arac rolüne" ilişkin çalışmada da liderlik tarzı ile cinsiyet arasında anlamlı bir ilişki olmadığının tespiti ile de desteklenmektedir.

Araştırmaya katılan turist rehberlerinin liderlik tarzlarının belirlenmesinde eğitim düzeylerinin anlamlı bir fark oluşturmadığı sonucuna ulaşılmıştır. Literatür incelendiğinde Korkmaz (2017) tarafından yapılan çalışmada da çalışanların eğitim düzeylerinin liderlik algısı ile anlamlı bir fark oluşturduğuna ilişkin ters yönde bir sonuca ulaştı̆̆ı gözlemlenmiştir. Turist rehberlerinin eğitim düzeylerinin yüksek olmasının, sundukları hizmetin kalitesinin artmasına ve ziyaretçilerde bırakacakları olumlu izlenimlerin çoğalmasına önemli ölçüde katkı sağlayabilecekleri düşünüldüğünde, lisans düzeyinde verilen eğitim dışında, yüksek lisans ve doktora eğitimleri ile de mesleki gelişimin devamlılığı sağlanarak bu olumlu katkıların daha da pekiştirilebileceği öngörülebilir.

Araştırmada elde edilen bulgulara göre; turist rehberlerinin çıktıkları turların büyük çoğunluğu günübirlik turlardan oluşmaktadır. Turist rehberlerinin liderlik tarzının belirlenmesinde çıkılan turun anlamlı bir fark oluşturmadığı sonucuna ulaşılmıştır. Turist rehberlerinin düzenli bir yaşam içinde yer alma ihtiyacının ve sektör içindeki çalışma günlerinin sınırlı olmasının günübirlik turların tercih edilmesinin sebebi olduğu düşünülebilir (Gökdemir ve Hacıŏlu, 2018). Diğer yandan, bulundukları bölgede hizmet vermelerinin daha kolay olması, birden fazla günü içeren turların sorumluluğunun daha yüksek ve seyahat süresinin daha uzun olması gibi sebeplerle de turist rehberlerinin günübirlik turları benimsedikleri ve mesleki faaliyetlerin sürdürdükleri ileri sürülebilir.

Turist rehberlerinin meslekte geçirmiş oldukları süre incelendiğinde turist rehberlerinin çoğunluğunun 6 ile 10 yıl arasında olduğu tespit edilmiştir. Yapılan analizler sonucunda turist rehberlerin liderlik tarzlarının belirlenmesinde meslekte geçirilen süreye göre anlamlı bir fark olmadığı sonucuna ulaşılmıştır. Yücel ve Akgül'ün (2016) çalışmasında da liderlik davranışlarının mesleki deneyime göre farklılık göstermediği tespit edilmiştir.

Turist rehberlerinin liderlik tarzlarından en yüksek ortalama ile otokratik liderlik davranışlarını "çoğunlukla" düzeyinde benimsedikleri anlaşılmaktadır. Yıldız ve Asunakutlu'nun (2017) çalışmasında da aile işletmelerinde çalışanların, yöneticilerinin davranışlarının diğer liderlik türlerine göre 
daha çok otokratik liderlik özelliği gösterdiklerini ifade etmekle birlikle, otokratik liderliğe ilişkin elde edilen sonuç çalışma bulgusunu desteklemektedir. Tur yönetiminin daha çok turist rehberinin kontrolü çerçevesinde gerçekleştirildiği izlenimiyle, uygulamada turun aksamaması ve başarılı bir şekilde tamamlanması için turist rehberlerinin otokratik liderlik tarzını benimsedikleri ileri sürülebilir. Turist rehberlerinin serbest bırakıcı lider özelliklerini "ara sıra" gösterirmiş oldukları belirlenmiş olup, bunun sebebinin tura katılan misafirlerin özelliklerinden ve onların tura olan ilgi düzeylerinden kaynaklı olabileceği düşünülmektedir. Diğer yandan, turist rehberlerinin otokratik ve serbest bırakıcı liderlik tarzları dışında, sergiledikleri liderlik davranışlarının aldıkları değerler bakımından sırasıyla etkileşimci liderlik, demokratik liderlik ve dönüşümcü liderlik özelliklerini "nadir" sıklıkta gerçekleştirmelerinin nedeninin, turist rehberleri ile hizmeti talep eden misafirler arasındaki etkileşimin, bu değerlere olumlu etki edebilecek düzeyde sağlanamamış olmasından kaynaklandığı düşünülebilir.

Turist rehberlerinin çalışma şekillerine göre otokratik liderlik boyutunda farklılık olduğu gözlemlenmiştir. Seyahat acentasına bağlı olarak çalışan turist rehberlerinin, serbest çalışan turist rehberlerine göre daha çok otokratik liderlik özellikleri gösterdikleri sonucuna ulaşılmıştır. Acentaya bağlı turist rehberlerinin çalışmanın devamlılığı açısından acenta ile sürekli bir iş ilişkisinin olması, turun acentanın belirlediği kurallar çerçevesinde yürütülmesinin aynı zamanda acentaya karşı sorumluğun da yerine getirilmesi anlamı taşıması sebebiyle, tur yönetiminde serbest çalışan turist rehberlerine göre daha otokratik liderlik davranışları sergiledikleri ifade edilebilir. Çalışma bulgularından bir diğeri de turist rehberlerinin mesleği icra etme şekillerine göre etkileşimci liderlik boyutunda anlamlı bir fark olduğunun tespitidir. Bu kapsamda, mesleği icra etme şekli "asıl iş" olan turist rehberlerinin mesleğin icrasını "ek iş" olarak yapan turist rehberlerine göre daha fazla etkileşimci liderlik özellikleri gösterdikleri sonucuna ulaşılmıştır. Mesleği asıl iş olarak yapan turist rehberlerinin, ek iş olarak yapan turist rehberlerine göre daha çok etkileşimci liderlik özellikleri göstermelerinin, çalışmanın devamlılığının sağlanması ve gelir elde etme ihtiyacının karşılanması noktasında alternatif bir seçeneklerinin olmayışından kaynaklandığ ileri sürülebilir. Ayrıca, rehberlik hizmetini asıl iş olarak yapan turist rehberlerinin daha fazla insanla iletişim halinde olacakları öngörüsüyle, etkileşimci liderlik özelliklerini mesleği ek iş 
olarak yapan turist rehberlerine göre daha çok sergiledikleri de düşünülebilir.

Turist rehberlerinin çalışma kartı türüne göre serbest bırakıc liderlik boyutunda anlamlı bir fark olduğu tespit edilmiş olup, tablodaki verilere göre çalışma kartı türü "ülkesel" nitelikte olan turist rehberlerinin çalışma kartı türü "bölgesel" olan turist rehberlerinden daha fazla serbest bırakıcı liderlik özelliklerini benimsedikleri sonucuna ulaşılmıştır. Turist rehberinin bir bölgede faaliyet göstermesinin o bölgedeki rehberlik hizmetine konu teşkil edecek değerlere olan hakimiyetinin, bir ülkedeki tüm turizm değerlerine olan hakimiyetinden daha fazla olabileceği söylenebilir. Bu kapsamda bölgesel olarak faaliyet gösteren turist rehberinin o bölgeye daha hâkim olması sebebiyle ülkesel olarak faaliyet gösteren turist rehberlerine göre daha az serbest bırakıcı liderlik özellikleri gösterdikleri ileri sürülebilir. Çalışmanın tüm bulguları ışığında Çanakkale Rehberler Odasına kayıtlı ve çalışma kartına sahip turist rehberlerinin liderlik tarzlarının daha çok otokratik liderlik özelliği gösterdiği düşünülmekle birlikte, gerek lisans eğitiminde, gerekse Turist Rehberleri Birliği' nin ve rehber odalarının öncülüğünde verilebilecek liderlik eğitimleriyle, turist rehberlerinin ve adaylarının mesleki gelişimlerine olumlu yönde katkı sağlanarak, benimsedikleri liderlik tarzına göre tur yönetimlerini gerçekleştirmelerinin hem kendileri hem de turizme değer katacağını söylemek mümkündür. 


\title{
EXTENDED ABSTRACT
}

\section{A Research on Determining the Leadership Type of Tourist Guides: The Sample of Canakkale Tourist Guides Chamber}

\author{
Sinan Gökdemir - Hacı Mehmet Yıldırım - Ayşegül Ateş \\ Çanakkale Onsekiz March University
}

Tourist guides, who play an active role in organizing the tours, are important stakeholders in the tourism sector. Tourist guides are the most effective tourism stakeholders in introducing and experiencing a destination to tourists. The leadership skills of tourist guides can provide them to be accepted as a leader by group, if they use their knowledge and skills to activate the group and pointed goals. Tourist guides, who play an effective role in the promotion of the destination and country visited, in the positive experiences of the visitors, convey information in the languages they want to those who are curious and want to learn that culture, as representatives of the culture they guide. In addition, tourist guides are the only people who, with their personal characteristics and social communication skills, contribute to meeting the expectations of tourists from the country / destination they visit and to establish a link between the culture of the visitor and the culture of the visitors (Kozak, 2017). In addition to affecting their satisfaction and generating positive results such as gaining their loyalty, it may also cause negative consequences such as dissatisfaction with the tour. Leadership is defined as an interpersonal interaction process, a task that can be fulfilled by people at all levels, which can make a group follow their own, with the aim of achieving the determined goals (Ulukan, 2006). According to Keçecioğlu (1998), leadership arising from a social influence process was expressed as the power of influencing other people with the characteristics possessed by individuals to achieve a certain goal.

The main purpose of the study is to determine the leadership types of the tour guides in Canakkale Chamber of Guides (ÇARO). The research population is 159 tourist guide who has a license from the Turkey Tourist Guides Association (TUREB) and registered to Canakkale Chamber of Tourist Gui- 
des (CARO). The sample of the research is 121 tourist guides who have licence from ÇARO. The Leadership Style Behavior Scale was used as data collection tool. In addition, questions for collecting demographic data of the participants were included. The Leadership Style Behavior Scale was developed by Taş et al. (2007). The scale, which includes 59 items, examines five subdimensions: autocratic leadership, democratic leadership, laissez-faire leadership, transformational leadership, and interactional leadership. Tourist guides registered in Çanakkale Tourist Guides Chamber constitute the population of the study. In the calculation of the research sample, the convenience sampling method, which is one of the non-probability sampling methods, was used due to the difficulties in reaching the participants due to the tourism season. Questionnaire was used as data collection tool in the study. Questionnaire created online and applied to the participants on social media; It has been collected in the period of April-June 2018. In total, the links were sent 121 guides on social media, and 102 people received feedback. Statistical analysis was made with the data obtained from the surveys.

According to the findings obtained in the research; most of the tours that tourist guides take are daily tours. It was concluded that the tour did not make a significant difference in determining the leadership style of the tourist guides. It can be thought that the need for tourist guides to take part in a regular life and the limited working days within the sector may be the reason why day tours are preferred (Gökdemir, 2017). On the other hand, it can be argued that tourist guides adopt daily tours and continue their professional activities due to reasons such as being easier to provide services in their region, higher responsibility for tours involving multiple days and longer travel time. It is understood that tourist guides adopt autocratic leadership behaviors at the level of "mostly" with the highest mean of leadership styles. In the study conducted by Yildız and Asunakutlu (2017), although it is stated that the behaviors of managers in family businesses show more autocratic leadership characteristics than other leadership types, the result obtained on autocratic leadership supports the study findings. With the impression that the tour management is mostly carried out within the framework of the control of the tourist guide, it can be argued that the tourist guides adopt the autocratic leadership style to ensure that the tour is not interrupted and completed successfully. It was determined that the tourist guides displayed the laissez- 
faire leadership behaviors "occasionally" and this may be due to the characteristics of the guests participating in the tour and their level of interest in the tour. On the other hand, apart from the autocratic and laissez-faire leadership styles of tourist guides, they rarely realize the characteristics of interactionist leadership, democratic leadership, and transformational leadership, respectively. The reason for this may be that the interaction between the tourist guides and the guests requesting the service was not provided at a sufficient level.

It has been observed that there is a difference in the dimension of autocratic leadership according to the working styles of tourist guides. It was concluded that tourist guides working under the travel agency display more autocratic leadership characteristics compared to freelance tourist guides. It can be stated that the tourist guides affiliated with the agency exhibit more autocratic leadership behaviors in tour management compared to self-employed tourist guides, since they have a permanent business relationship with the agency in terms of continuity of the work, and the fact that the tour is carried out within the framework of the rules determined by the agency also means fulfilling the responsibility towards the agency. Another finding of the study is that there is a significant difference in the interactionist leadership dimension according to the way tourist guides perform their profession. In this context, it was concluded that tourist guides, whose way of performing the profession is the permanent job, exhibit more interactive leadership characteristics than tourist guides who do their profession as part-time job. It can be argued that the fact that tourist guides, who do their permanent job, show more interactive leadership characteristics than tourist guides who do part-time job, are due to the lack of alternative options for ensuring the continuity of the work and meeting the need for income. In addition, it can be thought that tourist guides who perform guidance services as their permanent job, with the foresight that they will be in contact with more people, exhibit their interactionist leadership qualities more than tourist guides who do the job as an part-time job.

In the light of all the findings of the study, it is thought that the leadership styles of the tourist guides registered in Çanakkale Chamber of Guides are more autocratic, but by contributing positively to the professional development of tourist guides and candidates with leadership training, which can be given under the leadership of the Tourist Guides Association and guide 
chambers, It is possible to say that conducting tour management according to the leadership style they adopt will add value to both themselves and tourism.

\section{Kaynakça / References}

Ahipaşaoğlu, H. S. (2001). Turizmde rehberlik. Ankara: Detay Yayınclık.

Altunışık, R., Coşkun, R., Bayraktaroğlu, S. ve Yıldırım, E. (2012). Sosyal bilimlerde araşturma yöntemleri: SPSS uygulamal. İstanbul: Avcl Ofset.

Ardahan, F., Turgut, T. ve Kalkan Kaplan, A. (2016). Her yönüyle rekreasyon. Ankara: Detay Yayınclik.

Arslantürk, Y., Küçükergin, N. ve Apalı, Z. (2016). Turist rehberliği eğitiminde güncel durum ve kavram karmaşası. 17. Ulusal Turizm Kongresi, Muğla.

Arzi, S., ve Farahbod, L. (2014). Relationship of transformational and transactional leadership style with job satisfaction. Interdisciplinary Journal of Contemporary Research in Business, 6(3), 187-204.

Cohen, E. H., Ifergan, M., ve Cohen, E. (2002). A new paradigm in guiding: The Madrich as a role model. Annals of Tourism Research, 29(4), 919-932.

Çaylak, P., ve Tolon, M. (2014). Ağızdan Ağza Pazarlama ve Tüketicilerin Ağızdan Ağza Pazarlamayı Kullanımları Üzerine Bir Araştırma. Gazi Üniversitesi İktisadi ve İdari Bilimler Fakültesi Dergisi, 15(3), 1-30.

Çetin, F. (2011). Örgütsel vatandaşllk davranışlarmın açıklanmasında örgütsel bağlllk, iş tatmini, kişilik ve örgüt kültürünün rolü. Yayımlanmamış doktora tezi. Ankara Üniversitesi, Sosyal Bilimler Enstitüsü, Ankara.

Çolakoğlu, E. O., Efendi, E. ve Epik, F. (2017). Tur yönetimi ve turist rehberliği. Ankara: Detay Yayıncilik.

Coşar, M. (2011). Otantik liderlik kavramı ve ardilları üzerine bir araştırma. Yayımlanmamış yüksek lisans tezi. T. C. Kara Harp Okulu, Savunma Bilimleri Enstitüsü. Ankara.

Ulukan, M. (2006). Futbolcularm kulübe bağhllklarmda antrenörlerin liderlik özelliklerinin rolü. Yayımlanmamış yüksek lisans tezi, Selçuk Üniversitesi, Sosyal Bilimler Enstitüsü, Konya.

Gökdemir, S. (2017). Turist rehberlerinde iş doyumu ve tükenmişlik ilişkis: Bir alan araştırması. Yayımlanmamış doktora tezi, Balıkesir Üniversitesi, Sosyal Bilimler Enstitüsü, Balıkesir. 
İigüler, F. (2015). A research on tour gundes' use of emotional labor and the relationship between their job satısfaction and burnout levels: the sample of Izmir. Yayimlanmamış yükssek lisans tezi. İzmir Katip Çelebi Üniversitesi, Sosyal Bilimler Enstitüsü, İzmir.

Keçecioğlu, T. (1998). Liderlik ve liderler. İstanbul: KalDer Yayıncilık.

Korkmaz, O. (2017). Otantik liderlik ve örgütsel güven. The Journal of Academic Social Science Studies, 58, 437-454.

Kozak Akoğlan, M. (2017). Rekreasyonel liderlik ve turist rehberliği kavram ve kurumlar üzerinden bir analiz. Ankara: Detay Yayıncllı.

Köroğlu, Ö. (2017). İş doyumu ve motivasyon düzeylerini etkileyen faktörlerin performansla ilişkisi: Turist rehberleri üzerine bir araştırma. Yayımlanmamış doktora tezi. Balıkesir Üniversitesi, Sosyal Bilimler Enstitüsü, Balıkesir.

Russell, R.T. (2001). Leaderhip in recreation. New York: McGraw-Hill.

Sabuncuoğlu, Z. ve Tüz Vergiliel, M. (2016). Örgütesel davranış. Bursa: Aktüel Yayıncllk.

Soysal, A., Paksoy, H. M., veÖzçalc M. (2011). Kriz yönetiminde liderlik yeteneğinin bazı demografik değişkenler açısından incelenmesi. Girişimcilik ve Kalknma Dergisi, 6 (1), 222-248.

Taş, A., Çelik, K., ve Tomul, E. (2007). Yenilenen İlköğretim programının uygulandığı ilköğretim okullarındaki yöneticilerin liderlik tarzları. Pamukkale Üniversitesi Eğitim Fakültesi Dergisi, 22(22), 85-98.

Taşdöven, H., Emhan, A., ve Dönmez, M. (2012). Liderlik tarzı ve mizaç-karakter ilişkisi: polis teşkilatında bir uygulama. Yönetim ve Ekonomi: Celal Bayar Üniversitesi İktisadi ve İdari Bilimler Fakültesi Dergisi, 19(2), 165-177.

TDK, (2019). Rehber tanımı. 04 Haziran 2019 tarihinde http://www.tdk.gov.tr/index.php?option=com_bts\&arama=kelime\&guid=TDK.GTS.5b1489fa93aa47.72319534 adresinden erişildi.

Tosunoğlu, H. (2014). Liderlik tarzı algısının örgütsel bağhllk üzerindeki etkisinde örgüte güvenin aracı rolü: Bir örnek olay incelemesi. Yayımlanmamış yüksek lisans tezi). Hacettepe Üniversitesi, Sosyal Bilimler Enstitüsü, Ankara.

TUREB, (2019). Turist rehber sayllar istatistikleri. 24 Eylül 2019 tarihinde http://tureb.org.tr/tr/RehberIstatistik/ adresinden erişildi.

TUREB, (2019). Turist rehberliği meslek kanunu. 20 Eylül 2019 tarihinde http://www.tureb.org.tr/tr/Page/Detail/60 adresinden erişildi.

Ülgen, H. ve Mirze, S. K. (2010). İsletmelerde stratejik yönetim. İstanbul: Beta Yayıncllk. Yarcan, Ş. (2007). Profesyonel turist rehberliğinde mesleki etik üzerine kavramsal bir değerlendirme. Anatolia: Turizm Araştırmalan Dergisi. 18(1), 33-44. 
Yayla, Ö. (2014). Rekreasyon faaliyetlerinde liderlik. A. Yaylı (Ed.) Rekreasyona Giriş içinde (s. 156-162). Ankara: Detay Yayınclık.

Yazıcıŏlu, Y. ve Erdoğan, S. (2004). SPSS uygulamalı bilimsel araştırma yöntemleri. Ankara: Detay Yayınclik.

Yıldız, N.; Asunakutlu, T. (2017). Aile işletmelerinde liderlik ve örgütsel bağlılık ilişkisi üzerine bir araştırma. Social Sciences Studies Journal. 3(12), 2167-2178.

Yücel, İ. ve Akgül, İ. (2016). Liderlik stilleri ile örgütsel bağllık arasındaki ilişkide iş tatmininin araclık etkisi: Akademisyenler üzerine bir çalışma. C. Ü. İktisadi ve İdari Bilimler Dergisi, 17 (1), 209-226.

Wong, J. Y., ve Lee, W. H. (2012). Leadership through service: An exploratory study of the leadership styles of tour leaders. Tourism Management, 33(5), 1112-1121.

\section{Kaynakça Bilgisi / Citation Information}

Gökdemir S., Yıldırım, H. M. ve Ateş, A. (2020). Turist rehberlerinin liderlik tarzlarının belirlenmesine yönelik bir araştırma:Çanakkale rehberler odası örneği OPUS-Uluslararası Toplum Araştırmaları Dergisi, 16(Özel Say1), 3619-3641. DOI: 10.26466/opus.690593 